\title{
МОДЕЛЬ ФОРМУВАННЯ У МАЙБУТНІХ УЧИТЕЛІВ ГОТОВНОСТІ ДО ТОЛЕРАНТНОГО ВИХОВАННЯ МОЛОДШИХ ШКОЛЯРІВ
}

У статті розроблено та теоретично обірунтовано модель фрормування готовності майбутніх учителів до толерантного виховання молодших школярів як сформованої в результаті професійної підготовки інтегрованої якості педагога, певного мобілізаційного стану його професійної компетентності, що виявляється у комплексі здатностей і психологічних рис та охоплює когнітивну, емоційно-ціннісну, діяльнісно-комунікативну сфери, складниками якої є цільовий, організаційно-змістовий та діагностично-оцінний блоки.

На основі аналізу моделей, близьких за своєю сутністю до досліджуваних педагогічних процесів, враховуючи специфіку предмету дослідження та здійснені теоретичні узагальнення, компоненти моделі було логічно згруповано у три великі блоки: методологічний, організаційно-діяльнісний та результативний.

Методологію дослідження розроблено на основі низки теоретико-методологічних підходів, вибір яких зумовлювався особливостями предмету дослідження та опорою на останні досягнення педагогічної науки: аксіологічний, особистісно-зорієнтований, компетентнісний та ситуативний.

Саме ситуативний підхід, що передбачає занурення студентів у певну професійну ситуацію, розглядається як провідний в організаційно-діяльнісному блоці моделі.

Особливу увагу приділено механізму профресійної самореалізації здобувачів освіти у різноманітних виробничих ситуаціях або за умови організації квазіпрофресійної діяльності майбутніх учителів початкової школи, тобто розв'язання ними системи навчально-професійних педагогічних завдань різної складності.

Логічна класифрікація квазіпрофресійних ситуацій містить три їх групи: інфформаційні та проблемні ситуації; мотиваційні, емоційні та оціночні ситуації; алгоритмічно-діяльнісні, комунікативні та рефрлексійні ситуації. Наведена класифрікація має в основі завдання, які реалізує використання того чи іншого типу квазіпрофресійних ситуацій. Самі завдання випливають зі структури готовності майбутніх учителів до толерантного виховання молодших школярів.

Суттєвою відмінністю змістового складника експериментальної моделі фрормування у майбутніх учителів готовності до толерантного виховання молодших школярів визначено оновлення змісту нормативних навчальних дисциплін («Педагогіка», "Вступ до спеціальності», "Основи педагогічної майстерності» та інших) та педагогічної практики.

Ключові слова: професійна підготовка, толерантність, готовність до толерантного виховання учнів, модель формування готовності, квазіпрофесійні ситуації, структурні компоненти готовності.

Постановка проблеми. В умовах соціокультурних суспільних перетворень, модернізації сфери освіти постає модель фрахівця нової генерації, одним із компонентів якої є толерантність як особистісна та професійна якість, готовність до толерантного виховання учнів, спроможність культивувати толерантність у соціумі. Впроваджувана у практику сьогодення освітня модель, підпорядкована Закону про вищу школу та Національній доктрині розвитку освіти, вимогам Нової української школи, а також аналіз результатів окремих напрацювань 3 досліджуваного питання на чільне місце висувають той факт, що толерантний педагог початкової школи, завдяки особливій тактиці організації стосунків з учнями, досягає вагоміших результатів у своїй професійній діяльності.

Саме тому фундаментальними характеристиками професійної підготовки вчителів $є$ форму- вання їх готовності до толерантного виховання молодших школярів в умовах Нової української школи; підготовка до ефрективного вирішення професійних педагогічних завдань, пов'язаних з проблемами конфліктності, толерантної свідомості і поведінки в умовах полікультурного освітнього середовища на основі міждисциплінарного наукового знання і сучасних гуманітарних технологій.

Аналіз останніх досліджень і публікацій. Засадничі ідеї толерантності наскрізною лінією проведені в нормативно-правових документах системи освіти України: Законах України «Про освіту» (2017р.), «Про вищу освіту» (2014р.); Національній стратегії розвитку освіти в Україні на період до 2021 року (2013 р.); Концепції розвитку освіти України на період 2015-2025 рр. (2014р.); Стратегії сталого розвитку «Україна -2020» (2015); 
Концепції розвитку педагогічної освіти (2018); Концепції Нової української школи (2016) тощо.

Сучасні наукові розвідки свідчать, що проблема формування у майбутніх учителів готовності до толерантного виховання молодших школярів висвітлюється різноаспектно, а саме: вдосконалення освітнього процесу підготовки майбутніх учителів початкової школи (Н. Бібік, В.Бондар, О. Будник, Я. Кодлюк, Л. Коваль, А. Крамаренко, О. Кучерявий, О.Матвієнко, О. Савченко, Л. Хомич та інші); загальні питання педагогіки толерантності (М. Андреєв, О. Безкоровайна, О. Грива, Г. Коберник, Л. Москальова, Ю. Тодорцева та інші), фоомування педагогічної толерантності майбутніх вчителів та вчителів початкових класів (Т. Варенко, Ю. Гордієнко, Ю. Ірхіна, Р. Кострубань, І. Кривошапка та інші); моделювання процесу підготовки майбутніх учителів до формування толерантності учнів початкової школи (Н. Бирко, І. Сухопара) тощо.

Метою статті $\epsilon$ розробка та обґрунтування моделі формування у майбутніх учителів готовності до толерантного виховання молодших школярів.

Виклад основного матеріалу. Для вивчення особливостей роботи (функціонування) певної системи та її призначення у взаємозв'язку з внутрішніми та зовнішніми елементами створюється структурно-функкціональна модель. Під моделлю розуміють зображення, схему, графік будь-якого об'єкта, процесу або явища, що використовується як його спрощена заміна (3. Курлянд), теоретичний взірець-еталон процесу навчання (А. Пехота, А. Кіхтенко).

Процес створення моделі (моделювання), за твердженням В. Маслова, здійснюється на наукових засадах системного підходу і відображає творчий цілеспрямований процес конструктивно-проектної, аналітико-синтетичної діяльності з метою відображення об'єкта (системи) в цілому або його окремих складників, які визначають функціональну спрямованість, забезпечують стабільність існування та розвитку [8, с. 3-9].

Підґрунтям моделювання процесу формування у майбутніх учителів готовності до толерантного виховання молодших школярів $є$ аналіз близьких за своєю сутністю моделей педагогічних процесів, позаяк обізнаність із ними впливає на обґрунтованість вибору змісту, фрорм, методів, засобів, прийомів організації освітньої діяльності здобувачів освіти відповідно до конкретних умов [6, с. 88].

Найбільш близькою до предмету нашого дослідження $€$ модель підготовки майбутніх учителів до формування толерантності учнів початкової школи, розроблена Н. Бирко (2014р.). Структура моделі представлена дослідницею через взаємодію чотирьох компонентів (цільового, організаційного, змістово-процесуального та результативного), які забезпечують досягнення мети й очікуваного результату дослідження - високого рівня готовності майбутніх учителів до формування толерантності учнів початкової школи. Провідну роль реалізації змістово-процесуального компонента моделі відведено розробці й апробації спецкурсу «Основи педагогіки толерантності», теоретичним підґрунтям якого $€$ концептуальні засади ненасильницької взаємодії суб'єктів освітнього процесу, створення умов для розвитку толерантності учнів початкової школи в соціумі $[1$, с. 9].

Наступна модель - це модель формування педагогічної толерантності майбутніх учителів іноземних мов початкової школи, обґрунтована Ю. Гордієнко (2017р.). Ї̈̈ концепція ґрунтується на основних положеннях гуманістичної та гуманітарної парадигм освіти, а також на основі низки методологічних підходів. Цілісність моделі утворюють взаємопов'язані теоретико-методологічний, змістовий, методичний та практичний компоненти. Етапи фрормування педагогічної толерантності студентів (діагностичний, прогностичний, змістовий, процесуальний, результативний) відображають зміст компонентів розробленої моделі професійної підготовки майбутніх учителів засобами іноземних мов [4, с. 11, 12].

Найбільш ґрунтовною $€$ модель, покладена в основу системи професійної підготовки майбутніх вихователів до формування толерантності у дітей дошкільного віку, розроблена В. Ляпуновою (2017 р.). Названа модель передбачає не тільки наявність цільового і змістового компонентів, але і регламентує процесуально-психологічні умови, форми, методи, засоби та прогнозує результати. Реалізується в межах мотиваційно-ціннісного, фахово-збагачувального та рефлексивно-самостійного етапів [7, с. 233].

Враховуючи попередній досвід конструювання подібних моделей, специфріку нашого предмету дослідження та здійснені теоретичні узагальнення, було визначено логічним згрупувати компоненти моделі у три великі блоки: методологічний, організаційно-діяльнісний та результативний (Рис. 1).

Вихідним у побудові моделі було визначення готовності майбутніх учителів до толерантного виховання молодших школярів як сформованої в результаті професійної підготовки інтегрованої якості педагога, певного мобілізаційного стану його професійної компетентності, що виявляється у комплексі здатностей і психологічних рис та охоплює когнітивну, емоційно-ціннісну і діяльнісно-комунікативну сфери.

Розробляючи методологію дослідження, ми виходили з низки теоретико-методологічних підходів, вибір яких зумовлювався особливостями предмету дослідження та опорою на останні досягнення педагогічної науки, зумовлені теоретичним обґрунтуванням нової освіт- 


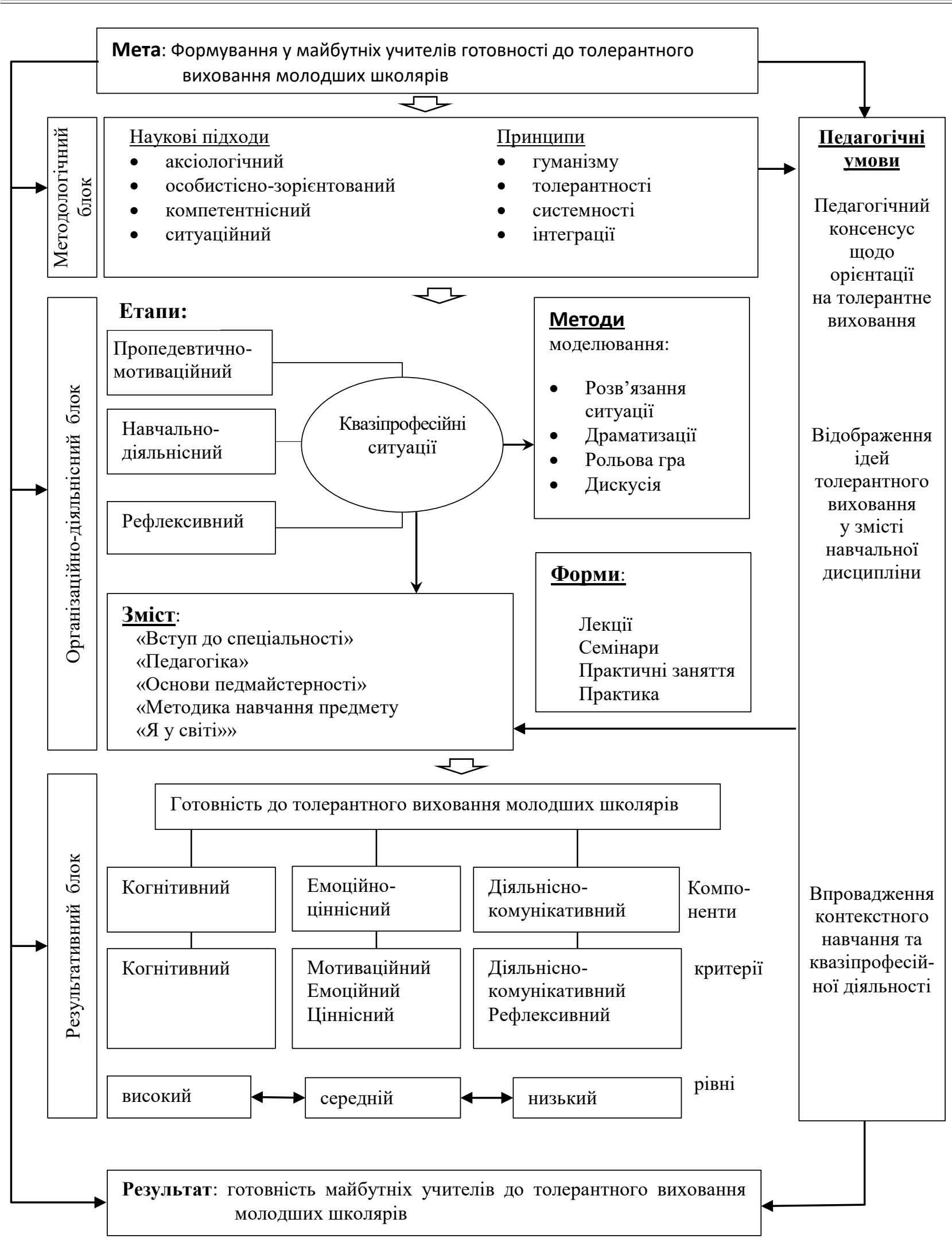

Рис. 1. Модель формування у майбутніх учителів готовності до толерантного виховання молодших школярів

ньої парадигми. Кожний з обраних підходів відігравав подвійну роль: слугував провідною ідеєю в побудові моделі підготовки майбутніх учителів та був арсеналом ідей і певним зразком в органі- зації процесу толерантного виховання молодших школярів. До таких підходів належать: аксіологічний, особистісно зорієнтований, компетентнісний та ситуативний. 
Аксіологічний підхід, на думку Т. Варенко, спрямовує вищу освіту на підготовку не знеособлених молодих кваліфікованих кадрів, а на досягнення результативності в загальному та профресійному розвитку особистості студента через розкриття його потенціалу; зміну звичних уявлень про її мету як формування систематизованих знань, умінь та навичок.

Таким чином, аксіологічний підхід до підготовки у майбутніх учителів готовності до толерантного виховання молодших школярів дозволяє визначити цінності, на які буде зорієнтований процес навчання та виховання у закладі вищої освіти й на основі яких будуть фрормуватися ціннісні орієнтації майбутніх фрахівців, необхідні їм для здійснення професійної діяльності в полікультурному суспільстві на засадах гуманізму, справедливості, поваги до представників інших культур та їхніх культурних надбань [3, с. 163].

У контексті підготовки майбутніх учителів початкової школи особистісно зорієнтований підхід здебільшого розглядається як ефективна стратегія становлення майбутнього педагога - активного суб'єкта професійної діяльності, де навчання студентів має набувати діалогічного характеру на засадах співпраці, довіри, відкритості та співтворчості, наявності зворотного зв'язку про розвиток і проблеми всіх учасників освітнього процесу (М. Чобітько); як засіб індивідуального проектування розвитку педагогічної майстерності, який спрямовує освітній процес на активізацію та розвиток емоційно-ціннісної сфери студентів на основі стимулювання їх інтересу до педагогічної профресії (Н. Гузій); як створення індивідуальної освітньої траєкторії кожного студента, забезпечення їх особистісно-професійного розвитку, прогнозування та подолання криз і відхилень у педагогічному становленні особистості (А. Цина).

Компетентнісний підхід полягає у визнанні компетентностей як кінцевого результату навчання та їхньому цілеспрямованому формуванні; перенесення наголосів з поінформованості суб'єктів навчання на вміння використовувати інформацію для розв'язання практичних проблем; спрямованість фрахової підготовки на майбутнє працевлаштування випускників (О. Гуренко [5], О. Заблоцька).

3 погляду компетентнісного підходу готовність майбутніх учителів до толерантного виховання молодших школярів виступає як певний (мобілізаційний) стан. На думку Л. Коваль, компетентнісний підхід в системі професійної підготовки майбутніх учителів початкової школи відіграє подвійну роль: модернізує зміст з одночасним визначенням результативного складника - набуття студентами компетентностей, та організує такий освітній процес, де цілеспрямовано відбувається підготовка педагогів до формування ключових і предметних компетентностей в учнів [6].
Головним шляхом реалізації цього підходу В. Бондар вважає забезпечення практичної спрямованості освіти, а саме механізму професійної самореалізації студентів у різноманітних виробничих ситуаціях [2] або за умови організації квазіпрофесійної діяльності майбутніх учителів початкової школи, тобто розв'язання ними системи навчально-професійних педагогічних задач різної складності (В. Желанова).

Ситуативний підхід спрямовує процес підготовки майбутніх учителів на вивчення конкретних явищ. На переконання О. Гуренко, в окресленому підході ключовим $€$ поняття ситуації, яка визначається як конкретна система обставин і умов, що найбільш сильно впливають на організацію [5].

Під ситуативним підходом до формування у майбутніх учителів готовності до толерантного виховання молодших школярів ми розуміємо занурення студентів у певну професійну ситуацію, яка передбачає розв'язання виховної проблеми на засадах толерантності, де вони можуть практично реалізувати свої знання, уміння, навички, цінності, досвід згідно з функціями майбутньої професійної діяльності. Ситуативний підхід розглядається нами як провідний в організаційно-діяльнісному блоці моделі.

Наступний, організаційно-діяльнісний блок моделі формування у майбутніх учителів готовності до толерантного виховання молодших школярів, містить етапи (пропедевтично-мотиваційний, навчально-діяльнісний, рефрлексивний) і зміст, який забезпечує фрормування всіх компонентів вищезгаданої готовності, але з певним наголосом на кожному з них.

Експериментальна модель формування у майбутніх учителів готовності до толерантного виховання молодших школярів передбачає оновлення змісту нормативних навчальних дисциплін («Педагогіка», «Вступ до спеціальності», «Основи педагогічної майстерності», «Методика навчання предмету «Я у світі», «Методика навчання української мови») та педагогічної практики.

Суттєвою відмінністю змістового складника моделі стала відмова від тематичного спецкурсу. Це було зумовлено кількома принциповими моментами, серед яких визначальними є наступні: введення спецкурсу потребує додаткової організаційної роботи та корекції навчальних планів, що не завжди збігається з існуючою традицією викладання; практичне значення дослідження, на наш погляд, має полягати в удосконаленні наявної практики. Тому в своїй моделі ми спиралися на зміст нормативних курсів, удосконалюючи їх шляхом введення певних сюжетів та акцентів.

3 огляду на те, що однією з провідних умов фрормування у майбутніх учителів готовності до толерантного виховання молодших школярів визначено квазіпрофесійну діяльність та кон- 
текстне навчання, а методологічною засадою ситуативний підхід, провідним методом реалізації моделі було обрано моделювання шляхом розв'язання педагогічних ситуацій.

Оскільки у структурі готовності майбутніх учителів до толерантного виховання молодших школярів нами було визначено когнітивний, емоційно-ціннісний та діяльнісно-комунікативний компоненти, то й квазіпрофесійні ситуації мають сприяти формуванню кожного з них. Таким чином, утворюється логічна класифікація квазіпрофесійної ситуації, яка включає три групи ситуацій.

Перша група ситуацій спрямована на фрормування когнітивного складника готовності майбутніх учителів до толерантного виховання молодших школярів і включає інформаційні та проблемні ситуації.

Друга група ситуацій має на меті формувати емоційно-ціннісний складник готовності майбутніх учителів до толерантного виховання молодших школярів і поєднує в собі мотиваційні, емоційні та оціночні ситуації.

Третя група ситуацій пов'язана з діяльнісно-комунікативним складником готовності майбутніх учителів до толерантного виховання молодших школярів. До неї входять алгоритмічно-діяльнісні, комунікативні та рефлексійні ситуації.

У запропонованій моделі педагогічна ситуація розглядається в двох площинах. Першою площиною $є$ підготовка майбутнього вчителя початкової школи, формування в нього готовності до толерантного виховання, де вона $є$ складником методу моделювання, засобом контекстного навчання та організації квазіпрофесійної діяльності. У цьому сенсі їх логічно називати квазіпрофе- сійними ситуаціями. Друга площина - сам процес толерантного виховання в початковій школі, в якому педагогічна ситуація відіграє роль методу виховання. Таким чином, квазіпрофесійна ситуація $€$ способом набуття майбутніми вчителями вміння створювати і розв'язувати виховні ситуації.

Таким чином, класифікація квазіпрофесійної ситуації та виховної ситуації мають бути ідентичними (Рис. 2).

Позаяк в основу організаційно-діяльнісного блоку моделі було покладено розв'язання квазіпрофесійної ситуації, що є складником методу моделювання в процесі фрормування готовності майбутніх учителів до толерантного виховання молодших школярів, перевага надавалася методам, безпосередньо з ним пов'язаним, насамперед тим, що належать до інтегративних: драматизація, рольова гра, дискусія, «мозковий штурм» тощо.

Результативний блок моделі представляє готовність майбутніх учителів до толерантного виховання молодших школярів як набуту під час реалізації моделі якість, що мають когнітивний, емоційно-ціннісний та діяльнісно-компетентісний складники. Ступінь сформованості цих складників вимірюється за когнітивним, мотиваційним, ціннісним, діяльнісним, комунікативним та рефлексивним критеріями і дозволить визначити рівень їі сформованості (високий, середній, низький).

Висновки. Отже, розроблена нами модель сприяє формуванню успішного вчителя початкової школи, здатного використовувати у виховному процесі теоретичні знання основ толерантного виховання, виявляти полікультурний світогляд, виявляти критичне мислення, мати

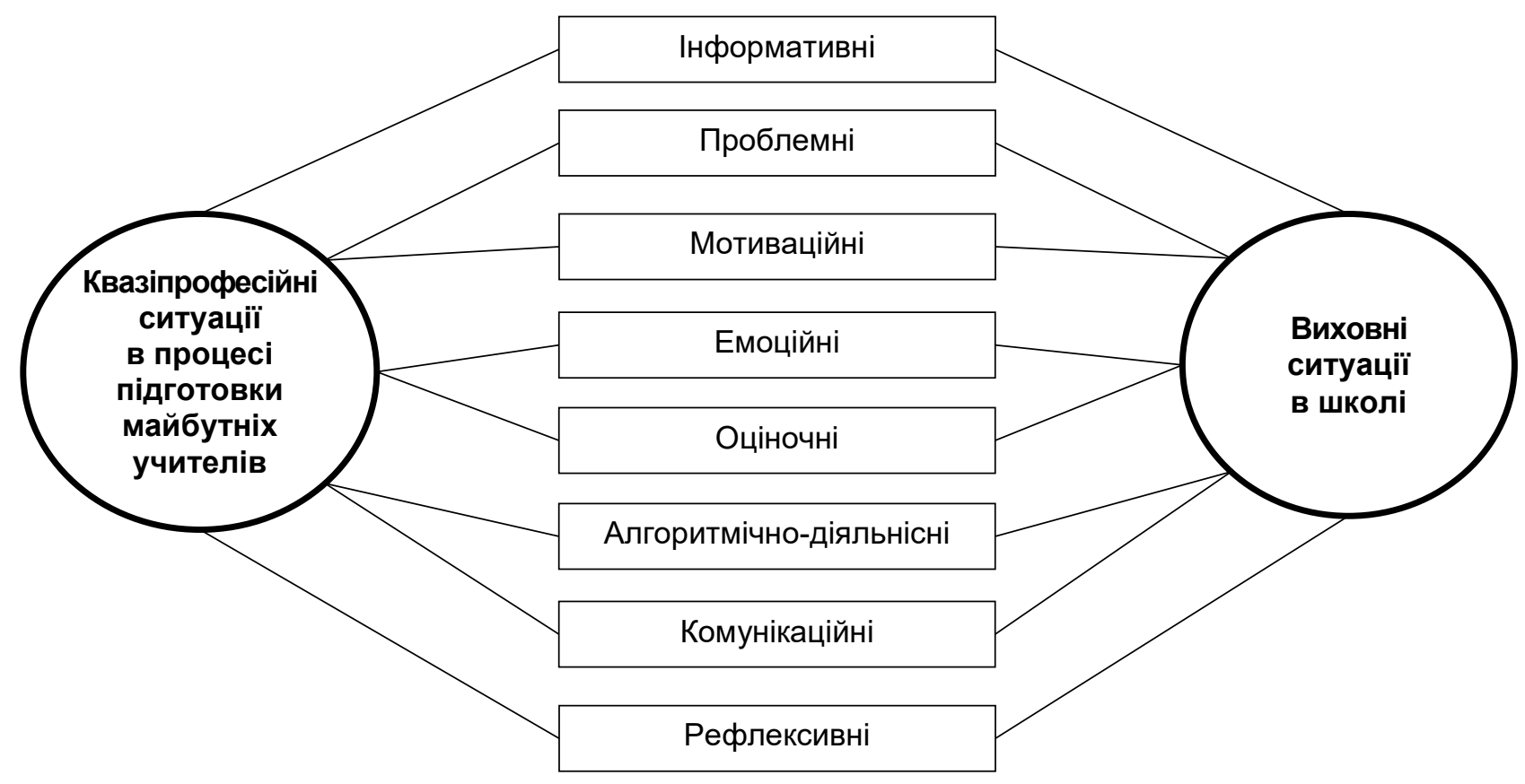

Рис. 2. Типи квазіпрофесійних та виховних ситуацій 
толерантну позицію як установку на толерантне виховання; визначати цілі, організовувати діяльність та оцінювати їі результати на основі усвідомлення самооцінки кожної особистості у різноманітних її проявах; здійснювати толерантне виховне середовище, реалізовувати педагогіку партнерства; усвідомлювати свою роль у толерантному вихованні, аналізувати власну виховну діяльність, визначати її сильні та слабкі сторони. Оптимальність і результативність процесу формування готовності майбутніх вчителів до толерантного виховання майбутніх школярів значною мірою забезпечується використанням у ньому квазіпрофесійних ситуацій.

\section{Список використаної літератури}

1. Бирко Н.М. Підготовка майбутніх учителів до формування толерантності учнів початкової школи : автореф. дис. канд. пед. наук : 13.00.04. Житомир, 2014. 20 с.

2. Бондар В.І., Шапошнікова І.М. Управління підготовкою успішного вчителя: теорія і практика : монографрія ова. Київ : Вид-во НПУ ім. М. П. Драгоманова, 2015. 331 с.

3. Варенко Т.К. Аксіологічний підхід та доцільність його реалізації в сучасній системі вищої педагогічної освіти. Педагогіка фрормування твор- чої особистості у вищій $і$ загальноосвітній школах. Запоріжжя: Класичний приватний університет, 2010. Випуск № 11 (64). С. 161-164. URL: http://pedagogy-journal.kpu.zp.ua/archive/ 2010/11/28.pdf.

4. Гордієнко Ю.А. Формування педагогічної толерантності майбутніх учителів іноземних мов початкової школи : автореф. дис. канд. пед. наук : спеціальність 13.00.04. Київ, 2017. 21 с.

5. Гуренко О. Полікультурна освіта майбутніх соціальних педагогів: теоретико-методичний аспект : монографія. Бердянськ : Видавець Ткачук О.В., 2014. 588 с.

6. Коваль Л. Професійна підготовка майбутніх учителів у контексті розвитку сучасної початкової освіти: технологічний підхід : монографія. Донецьк : ЛАНДОН-XXI, 2011. 330 с.

7. Ляпунова В.А. Теоретичні і методичні засади професійної підготовки майбутніх вихователів до формування толерантності дітей у дошкільних навчальних закладах : дис. докт. пед. наук: спеціальність 13.00.04 - теорія та методика професійної освіти; 13.00.08 - дошкільна педагогіка. Мелітополь, 2017.

8. Маслов В.І. Моделювання у теоретичній і практичній діяльності в педагогіці. Післядипломна освіта в Україні. 2008. № 1. С. 3-9.

\section{Cherednyk L. Readiness for tolerant education of younger schoolchildren future teachers formation model}

The article theoretically substantiates and develops a model for the formation of the of future teachers readiness for the tolerant education of younger schoolchildren as a teacher who has developed an integrated quality of the teacher, a certain mobilization state of his professional competence, which manifests itself in a complex of abilities and psychological traits, covers cognitive, emotionally valuable, actively -communicative sphere, the components of which are targeted, organizational and substantive diagnosticity-estimated blocks.

Based on essentially similar models analysis to the studied pedagogical processes, taking into account the specifics of the researched subject and the theoretical generalizations, the components of the model, were logically grouped into three big blocks: methodological, organizational-activity and efficient-based blocks.

The methodology of the research was developed based on numerous theoretical and methodological approaches, the choice of which was determined by the peculiarities of the subject of research and reliance on the latest achievements of pedagogical science: axiological, personally oriented, competent and situational accomplishments.

It is a situational approach is considered as a leading model in the organizational and activity block. This approach involves students engaging in a certain professional situation.

Particular attention is given to the mechanism of professional self-realization of the future primary school teachers in various industrial situations or to cases where they are under the condition of organizing quasiprofessional activities, which means they have to solve the system of different complexity educational and professional-pedagogical tasks.

The logical classification of quasi-professional situations consists of three groups: information and problem situations; motivational, emotional and evaluative situations; algorithmic-activity, communication and reflection situations. The above classification is based on a task that implements the use of a particular type of quasiprofessional situation. The tasks themselves arise from the structure of future teachers'readiness for the tolerant education of younger students.

The significant difference between the content component of the experimental model of future teachers' readiness for the tolerant education of pupils is the updating of the content of normative educational disciplines ("Pedagogy", "Introduction to the specialty", "Fundamentals of pedagogical skill" and other) and the pedagogical practice.

Key words: vocational training, readiness for tolerant education of students, readiness model formation, quasi-professional situations, structural components of readiness. 